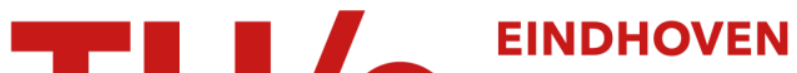 \\ UNIVERSITY OF \\ TECHNOLOGY
}

\section{Strong density gradients in postdischarges in argon and air}

\section{Citation for published version (APA):}

Liu, Z., Veldhuizen, van, E. M., Heesch, van, E. J. M., \& Pemen, A. J. M. (2011). Strong density gradients in postdischarges in argon and air. IEEE Transactions on Plasma Science, 39(11), 2092-2093.

https://doi.org/10.1109/TPS.2011.2156418

DOI:

10.1109/TPS.2011.2156418

Document status and date:

Published: 01/01/2011

\section{Document Version:}

Publisher's PDF, also known as Version of Record (includes final page, issue and volume numbers)

\section{Please check the document version of this publication:}

- A submitted manuscript is the version of the article upon submission and before peer-review. There can be important differences between the submitted version and the official published version of record. People interested in the research are advised to contact the author for the final version of the publication, or visit the $\mathrm{DOI}$ to the publisher's website.

- The final author version and the galley proof are versions of the publication after peer review.

- The final published version features the final layout of the paper including the volume, issue and page numbers.

Link to publication

\section{General rights}

Copyright and moral rights for the publications made accessible in the public portal are retained by the authors and/or other copyright owners and it is a condition of accessing publications that users recognise and abide by the legal requirements associated with these rights.

- Users may download and print one copy of any publication from the public portal for the purpose of private study or research.

- You may not further distribute the material or use it for any profit-making activity or commercial gain

- You may freely distribute the URL identifying the publication in the public portal.

If the publication is distributed under the terms of Article 25fa of the Dutch Copyright Act, indicated by the "Taverne" license above, please follow below link for the End User Agreement:

www.tue.nl/taverne

Take down policy

If you believe that this document breaches copyright please contact us at:

openaccess@tue.nl

providing details and we will investigate your claim. 


\title{
Strong Density Gradients in Postdischarges in Argon and Air
}

\author{
Z. Liu, E. M. van Veldhuizen, E. J. M. van Heesch, and A. J. M. Pemen
}

\begin{abstract}
High current sparks are created in argon and air using a high-voltage pulse of 16-ns duration. Shadowgraphy is applied to image density fluctuations. Shock waves become visible $\sim 100 \mathrm{~ns}$ after the pulse; they expand with a velocity somewhat higher than the speed of sound. The filamentary core of the discharge shows heating that diffuses outward slowly and develops into microturbulences. They remain visible up to $3 \mathrm{~ms}$. In air, the current remains lower than that in argon, and shocks only emerge from the electrodes. No indication of absorption is found; probably gas heating is observed near the electrodes.
\end{abstract}

Index Terms-Microturbulence, overvolted pulsed discharge, shadowgraphy, shock waves.

$\mathbf{V}$ OLTAGE PULSES with a 7-ns rise time and a 16-ns FWHM have been applied to two opposing arrays of eight points. The vertical distance between the anode and cathode points is $14 \mathrm{~mm}$; the horizontal distance between the points is $9 \mathrm{~mm}$. The amplitude of the voltage pulse is $\sim 60 \mathrm{kV}$, so the gap is strongly overvolted. Due to this high voltage, the initial streamer travels at $\sim 3-10 \mathrm{~mm} / \mathrm{ns}$ [1]. This implies that the gap is bridged well within $16 \mathrm{~ns}$ of the pulse duration. After bridging, the discharge goes over into a spark, and the current goes up to as much as the power supply can deliver. The present power supply has inductive storage with a diode opening switch [2] and is able to deliver a current of up to $200 \mathrm{~A}$ in argon and $100 \mathrm{~A}$ in air. The total energy per single discharge is $\sim 10 \mathrm{~mJ}$ in argon and $\sim 5 \mathrm{~mJ}$ in air. In [3], a current of $2 \mathrm{kA}$ is reported for a pulse in air with $60 \mathrm{kV}$ in a 50-mm gap. Due to the high current, the optical emission is sufficient for direct imaging using a CCD camera without an intensifier (SBIG STC-10). These time-integrated pictures are made, with a resolution of $1600 \times 1200$ pixels.

The top row of Fig. 1 shows the discharge in argon at 1 bar. It is seen that the paths are far from straight, the intensity per pin is varying significantly, and, most surprisingly, each

Manuscript received November 25, 2010; accepted May 5, 2011. Date of publication June 9, 2011; date of current version November 9, 2011. This work was supported by the Stichting Technische Wetenschappen under Grant OTP-06501.

Z. Liu is with the Department of Chemical and Biological Engineering, Zhejiang University, Hangzhou 310058, China (e-mail: 'zliu'zliu@ @ju.edu.cn).

E. M. van Veldhuizen is with the Department of Applied Physics, Technische Universiteit Eindhoven, 5600 MB Eindhoven, The Netherlands (e-mail: e.m.v.veldhuizen@tue.nl).

E. J. M. van Heesch and A. J. M. Pemen are with the Department of Electrical Engineering, Technische Universiteit Eindhoven, 5600 MB Eindhoven, The Netherlands (e-mail: e.j.m.v.heesch@tue.nl; a.j.m.pemen@tue.nl).

Digital Object Identifier 10.1109/TPS.2011.2156418 discharge channel consists, unexpectedly, of very fine filaments. The thinnest channels seen in Fig. 1 have an estimated FWHM of $100 \mu \mathrm{m}$. The lower left of Fig. 1 shows two discharge channels in air at 1 bar; the intensity in the bulk of the channels is, on average, 30 times lower than that in argon. It can be seen that the discharge in air is more diffuse; occasionally, two channels occur, and there is always a contraction in the center of the gap.

The middle row of Fig. 1 shows the shadowgraphs made with UV laser pulses of $8 \mathrm{~ns}$. The SBIG camera records the light from a fluorescent plate $10 \mathrm{~cm}$ behind the discharge. A series of photographs taken with different delays after the start of the voltage pulse is shown. Before $0.16 \mu \mathrm{s}$, almost nothing is seen, and from that time, the discharge and a corresponding shock wave develop. The shock wave travels at $\sim 400 \mathrm{~m} / \mathrm{s}$, slightly faster than the sound velocity in argon $(323 \mathrm{~m} / \mathrm{s})$. The central channels broaden with a speed of $\sim 100 \mathrm{~m} / \mathrm{s}$ until $5 \mu \mathrm{s}$. From that moment, this speed decreases rapidly, and at $1 \mathrm{~ms}$, it is down to $\sim 1-2 \mathrm{~m} / \mathrm{s}$. This transition appears to coincide with the formation of "bubbles"; they are also called microturbulences. At 3-4 ms, all density variations have disappeared. Shadowgraph photographs of pulses in air are far less spectacular. Almost nothing is seen of the central channels, but the circular shock waves starting at the points are more pronounced. These shocks expand with $\sim 360 \mathrm{~m} / \mathrm{s}$, again slightly faster than the sound speed in air $(343 \mathrm{~m} / \mathrm{s})$.

The pictures of the shock waves in air show faint gray stripes going from the cathode almost to the middle of the gap. In [4], such effects are attributed to absorption by ozone created by the discharge. The amount of absorption in the center of the gap could not be quantified, and in the measurements shown here, it disappears in the noise. Near the electrode tips, white edges can just be seen around darker areas. This points to density gradients, probably due to gas heating. This may be the reason why we do not observe ozone absorption.

\section{REFERENCES}

[1] A. G. Rep'ev and P. B. Repin, "Dynamics of the optical emission from a high-voltage diffuse discharge in a rod-plane electrode system in atmospheric air," Plasma Phys. Rep., vol. 32, no. 1, pp. 72-78, Jan. 2006.

[2] A. J. M. Pemen, I. V. Grekhov, E. J. M. van Heesch, K. Yan, S. A. Nair, and S. V. Korotkov, "Pulsed corona generation using a diode-based pulsed power generation," Rev. Sci. Instrum., vol. 74, no. 10, pp. 4361-4365, Oct. 2003.

[3] S. B. Leonov and D. A. Yarantsev, "Instability in postdischarge thermal cavity," IEEE Trans. Plasma Sci., vol. 36, no. 4, pp. 978-979, Aug. 2008.

[4] R. Ono and T. Oda, "Ozone production process in pulsed positive dielectric barrier discharge," J. Phys. D, Appl. Phys., vol. 40, no. 1, pp. 176-182, Jan. 2007. 

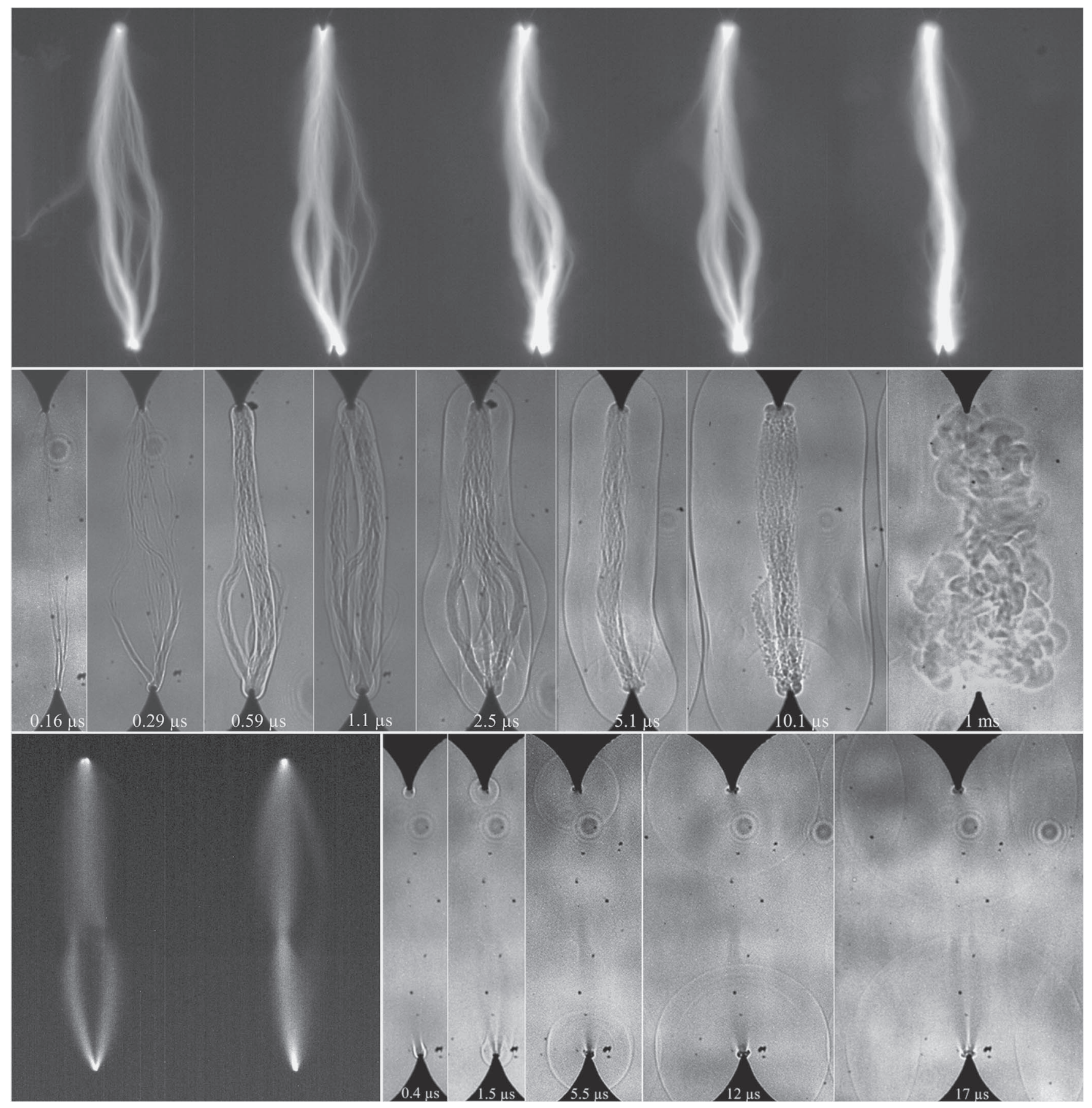

Fig. 1. In all images, the cathode is at the bottom, and the anode is at the top. The current per pin is $\sim 25 \mathrm{~A}$ in argon and $\sim 12 \mathrm{~A}$ in air. Note that, usually, most details are seen using a digital document and a computer screen. (Top row) Direct optical emission of sparks in argon. This emission has the same duration as the current, i.e., $16 \mathrm{~ns}$. The electrodes have eight pins of which five are displayed in this photograph. Most remarkable are the very thin filaments in combination with two or three thicker and more intense cores. (Middle row) Shadowgraphs in argon with delayed exposure times as indicated at the lower electrode. Shock waves develop around the discharge channels and much more faintly at the electrode tips. The central channel disintegrates into microturbulences. (Lower left row) Direct optical emission of sparks in air; here, only one or two diffuse channels appear. The contraction in the center is always observed. (Lower right row) Shadowgraphs in air: Circular shock waves develop only from the cathode and anode tips. The tiny circles at the electrodes and the faint stripes from the cathode to the middle of the gap are attributed to gas heating. 